\title{
The use of dextroketamine as postoperative adjuvant analgesia in a patient undergoing thoracotomy. Case report*
}

\author{
Uso de dextrocetamina como adjuvante de analgesia pós-operatória em paciente submetido a \\ toracotomia. Relato de caso
}

Vanise Barros Rodrigues da Mota', Nildany Reis e Brito², Alba Maria Soares Moraes ${ }^{3}$

${ }^{*}$ Received from Federal University of Maranhão, São Luís, MA, Brazil.

DOI 10.5935/1806-0013.20150015

\section{ABSTRACT}

BACKGROUND AND OBJECTIVES: Pain is a major source of stress for patients in the postoperative period, impairing recovery, mobility and hospital discharge. This study aimed at presenting the use of intravenous dextroketamine to treat a patient with severe postoperative pain in intensive care unit. CASE REPORT: Male patient, 36 years old, single, Caucasian, fisherman, living in the city of São Luís, submitted to major thoracic tumor removal (Shwanomma) with severe pain not controlled with opioids and simple analgesics, being necessary the use of adjuvants such as continuous intravenous dextroketamine, which has allowed mechanical ventilation weaning and patient's recovery in the postoperative period.

CONCLUSION: Low-dose intravenous dextroketamine associated to morphine has shown good safety and better control of severe postoperative pain in patient submitted to thoracotomy and admitted to an intensive care unit.

Keywords: Dextroketamine, Difficult to control pain, Intensive care unit, Postoperative period.

\section{RESUMO}

JUSTIFICATIVA E OBJETIVOS: A dor é uma grande fonte de estresse em pacientes no período pós-operatório, dificultando a recuperação, mobilidade e alta. O objetivo deste estudo foi mostrar a utilização de dextrocetamina por via venosa no tratamento de um paciente com dor intensa pós-operatória em unidade de terapia intensiva.

1. Federal University of Maranhão, Department of Anesthesiology, São Luís, MA, Brazil.

2. Federal University of Maranhão, School of Medicine, São Luís, MA, Brazil.

3. Federal University of Maranhão, Department of Speech Therapy, São Luís, MA, Brazil.

Submitted in November 20, 2014.

Accepted for publication in February 14, 2015.

Conflict of interests: none - Sponsoring sources: none.

\section{Correspondence to:}

Vanise Barros Rodrigues da Motta

Rua dos Gerânios, 01. Ed. Península Way. Torre Pontal. Apto 601

65077-550 São Luís, MA, Brasil.

E-mail: vanisem@globo.com

(C) Sociedade Brasileira para o Estudo da Dor
RELATO DO CASO: Paciente do gênero masculino, 36 anos, solteiro, branco, pescador, natural residente de São Luís submetido a exérese de grande tumoração torácica (Shwanomma) com ocorrência de dor intensa náo controlada com opioides e analgésicos simples, sendo necessário uso de adjuvantes como a dextrocetamina endovenosa contínua, o que possibilitou o desmame de ventilação mecânica e reabilitação do paciente durante o pós operatório.

CONCLUSÁO: A dextrocetamina por via venosa em baixas doses, associada à morfina demonstrou boa segurança e melhor efeito no controle da dor pós-operatória de forte intensidade em paciente submetido a toracotomia e internado em unidade de terapia intensiva.

Descritores: Dextrocetamina, Dor de difícil controle, Pós-operatório, Unidade de terapia intensiva.

\section{INTRODUCTION}

Acute postoperative pain management is still a challenge, notwithstanding analgesic techniques evolution. Pain is difficult to control in certain patients, which generates stress and suffering for patients and the team, so any effort is important to relieve such complaint. Drug combination has been suggested and different medications have been used for this type of patient ${ }^{1}$.

Ketamine is N-methyl-D-aspartate (NMDA) receptor blocker initially used for anesthetic effects. Currently, as from the understanding of its anti-hyperalgesic and antiallodynic effects, it has been used as adjuvant to treat difficult to control pain, be it acute or chronic. Several administration routes have been proposed, but most studies mention the intravenous route ${ }^{2}$.

This study aimed at reporting the use of intravenous dextroketamine to treat a patient with difficult to control postoperative pain in intensive care unit.

\section{CASE REPORT}

Male patient, 36 years old, single, Caucasian, fisherman, living in the city of São Luís, presented previous history of severe chest, upper limb and head pressing and pressure pain, without irradiation or improvement or worsening factors. After five months he noticed sternal manubrium bulging with 
progressive and fast growth, when he looked for medical care. CT has evidenced tumor adhered to the sternum and biopsy has confirmed that it was a Schwannoma. Patient was referred to the intensive care unit (ICU) by the operating center after thoracotomy for tumor resection, being hemodynamically stable and awaken (Glasgow 15). Central venous catheter was installed in right jugular vein; mean blood pressure in right radial artery; chest drains n. 36 right and 38 left; two aspirator drains in subcutaneous cell tissue; indwelling urinary catheter.

Surgery was performed under general anesthesia without intercurrences. It was not possible to install epidural catheter for postoperative analgesia. Patient was admitted to the ICU and was intubated still with residual anesthesia. When he started to return to consciousness he was agitated and uncomfortable in the ventilator. Asked by the team, he confirmed the presence of severe pain. Tramadol (100mg) and dipirone $(30 \mathrm{mg} / \mathrm{kg} /$ dose) were started without satisfactory results. Prescription was changed to bolus morphine, also without improvement. The ICU team decided to use continuous intravenous (IV) fentanyl and to ask Pain Service opinion. Non-steroid anti-inflammatory drug was not used because it was a surgery with major resection area and risk of bleeding.

According to the Pain Service recommendation, intravenous morphine was added and progressively titrated until $120 \mathrm{mg} /$ day. This allowed the withdrawal of fentanyl, providing patient emergence and mechanical ventilation weaning. In the first postoperative day patient was extubated and pain was evaluated by the numerical scale (NS) with is routine of the sector (implemented $5^{\text {th }}$ signal protocol). Patient referred very severe pain $(\mathrm{NS}=10 / 10)$ which has generated new morphine adjustment. In the second postoperative day, due to severe pain persistence, difficulty of inspiration due to pain, impossibility of receiving physiotherapy and airways hygiene by expectoration, dextroketamine was prescribed in $100 \mathrm{mg}$ solution diluted in $98 \mathrm{~mL}$ of $0.9 \%$ saline in infusion pump (IP), started at $0.1 \mathrm{mg} / \mathrm{kg} / \mathrm{h}$, associated with to intravenous morphine and diazepam, one tablet at night, due to patient's high anxiety. This schedule has improved pain $(\mathrm{NS}=3 / 10)$ allowing for physiotherapy assistance and respiratory pattern improvement. In the third postoperative day, drug doses were decreased, which has generated pain exacerbation episodes $(\mathrm{NS}=6 / 10)$ associated to worsening of cough, which has led to return to initial dextroketamine dose. It is worth highlighting that the whole team was very concerned with the use of ketamine in IP, which was a new procedure for the unit. Patient has evolved with hypertension episodes during the use of dextroketamine (maximum of $156 / 110 \mathrm{mmHg}$ ). In the seventh postoperative day, patient had a new severe pain episode, leading to new morphine dose adjustment. Diazepam was prescribed twice a day to improve anxiety control and patient has evolved with satisfactory pain control (NS=4/10).

While under dextroketamine, patient was evaluated by a speech therapist, who evidenced that he had maintained understandable and expressive speech, altered voice quality, speech articulation and maximum phonation time due to tachypnea.
Phonoarticulatory organs (lips, tongue, cheeks) had functional mobility, preserved sensitivity and normal tone. Patient presented voluntary and at request swallowing, presence of cough reflex and normal cervical auscultation. Patient ingested liquid foods, had myofunctional control and functional oropharingeal transit time, adequate hyolaryngeal complex excursion, however, with multiple swallowings as protective resource. After evaluation, it was suggested the oral route assisted and managed by the speech therapist to prevent bronchoaspiration and to promote safe and functional swallowing during the period he remained in the ICU.

It was possible to perform physiotherapy in the sense of noninvasive ventilation to prevent lung atelectasis and improve respiratory pattern. This assistance was optimized by patient's contribution to maneuvers after dextroketamine installation. There has also been early ambulation in the third postoperative day.

Patient was slightly sleepy, however awaken, making contact and walking during the whole period of dextroketamine use. Patient was maintained in spontaneous ventilation with oxygen catheter and hemodinamically stable without vasoactive drug throughout hospitalization. Patient was kept in the ICU with controlled pain (NS=3-4/10) and ketamine was withdrawn in the eighth hospitalization day. He was discharged from the ICU to the ward with morphine and dipirone, both switched to the oral route without intercurrences.

\section{DISCUSSION}

The World Health Organization (WHO) has developed an analgesic ladder to treat cancer pain, based on pharmacological measures involving anti-inflammatory drugs, opioids and adjuvants ${ }^{3}$ Pain management organization and standardization is based on a three-step ladder according to pain intensity presented by patients. The first step recommends the use of simple analgesics and anti-inflammatory drugs for mild pain $(\mathrm{NS}=1-3 / 10)$. The second step suggests weak opioids, which may be associated to first step simple analgesics or anti-inflammatory drugs, for moderate pain (NS=4-6/10). The third step suggests strong opioids, associated or not to simple analgesics or anti-inflammatory drugs, for severe pain (NS=7-10/10). Adjuvants may be used in the three steps of the ladder. The three-step ladder indicates specific classes of pharmacological and non-pharmacological approaches, providing physicians with flexibility and possibility of adaptation according to patients' peculiarities. WHO analgesic ladder has been worldwide used as guidance for pain management in general, including acute postoperative pain, and this was observed during the follow-up of our patient.

In major surgeries, such as in this case, it is recommended the use of catheter for epidural analgesia, which is an extremely widespread practice to treat post-thoracotomy pain. It provides preventive analgesia decreasing the possibility of central sensitization and of situations such as hyperalgesia, allodynia and continuous pain ${ }^{4}$. Authors have shown that epidural postoperative analgesia results in shorter ICU stay, pulmonary 
function improvement, less thromboembolic and cardiovascular complications, earlier mobilization and bowel function return, and shorter hospital stay ${ }^{5}$. In our case, it was impossible to install the epidural catheter due to technical difficulty. In some cases pain is difficult to control being necessary the addition of adjuvant drugs. Antidepressants, anticonvulsants, adrenergic agonists, local anesthetics, sodium channel blockers, NMDS receptor blockers, GABA receptors agonists and many others are used for this purpose ${ }^{1}$.

Ketamine, which is an NMDA receptors blocker, was synthesized for the first time in 1962 by American pharmacist Calvin Stevens in the Parke \& Davis laboratory. It may be clinically used in its racemic form or as isomer; dextroketamine is available in Brazil for more than ten years. Dextroketamine is considered 3 to 4 times more potent for pain relief and, in equianalgesic doses, produces less psychic changes and agitation as compared to the racemic form ${ }^{6,7}$. Ketamine acts both on the competitive NMDA receptors blockade and on non-competitive NMDA receptors blockade typical of glutamate, in addition to interacting with both spinal and supra-segmental opioid receptors. In low doses, it induces satisfactory analgesia, evidencing nociceptive system inhibition with central sensitivity blockade ${ }^{8}$.

Currently, dextroketamine is widely used as analgesic therapy adjuvant in humans, in spite of the lack of studies confirming its effectiveness and of discussions with regard to its routine clinical use. Some authors have shown that low dextroketamine doses associated to morphine potentiate analgesia and decrease opioids adverse effects, as well as its ability to decrease pain scores ${ }^{9}$. A large prospective study has shown safety of intravenous dextroketamine and morphine for patient-controlled analgesia ${ }^{10}$.

In a systematic review of ketamine for postoperative analgesia, authors have concluded that intravenous ketamine is an effective adjuvant, decreases opioid consumption, improves pain control quality, with special benefits for more painful procedures, such as high abdominal surgeries, thoracotomies and major orthopedic interventions ${ }^{11}$. However, there is no consensus in this review about the optimal dose to be used. With regard to adverse effects, ketamine does not effectively protect airways of patients susceptible to bronchoaspiration. It stimulates salivary secretion, which may increase the inci- dence of bronchspasm, in spite of its known bronchodilator effect $^{12}$. As described in this report (speech therapy evaluation) patient had good swallowing control with dextroketamine continuous infusion. There has been blood pressure increase, however with no need for anti-hypertensive therapy. It is also known that anxiety and pain increase blood pressure, which may have contributed to reported measures. There has been no hallucination, which has been primarily associated to low dextroketamine dose used in the infusion.

\section{CONCLUSION}

As from this case, it could be observed that pain control in certain patients is a hard task and the use of combined analgesia tends to be advantageous. Low intravenous dextroketamine dose associated to morphine was safe and provided better postoperative pain control in a patient with severe pain in the ICU. Patient was comfortable and less anxious after pain control, allowing for better quality of assistance.

\section{REFERENCES}

1. Gasparini JR, Saraiva RA. Tratamento de dor em paciente com tumor sacral inoperável. Relato de caso. Rev Bras Anestesiol. 2004;54(2):252-60.

2. Azevedo VM, Lauretti GR, Pereira NL, Reis MJ. Transdermal ketamine as an adjuvant for postoperative analgesia after abdominal gynecological surgery using lidocaine epidural blockade. Anesth Analg. 2000;91(6):1479-82.

3. Vargas-Schaffer G. Is the WHO analgesic ladder still valid? Twenty-four years of experience. Can Fam Physician. 2010;56(6):514-7.

4. Gianferrari P, Voltolina M, Clara ME, Marzullo A, Campra D. Postoperative pain management: epidural analgesia. Minerva Chir. 2003;58(6):857-60.

5. Carli F, Mayo N, Klubien K, Schricker T, Trudel J, Belliveau P. Epidural analgesia enhances functional exercise capacity and health-related quality of life after colonic surgery: results of a randomized trial. Anesthesiology. 2002;97(3):540-9.

6. Silva FC, Dantas RT, Citó MC, Silva MI, Vasconcelos SM, Fonteles MM, et al. Ketamina, da anestesia ao uso abusivo: artigo de revisão. Rev Neuroci. 2010;18(2): 227-37.

7. Koinig H, Marhofer P, Krenn CG, Klimscha W, Wildling E, Erlacher W, et al. Analgesics effects of caudal and intramuscular $S(+)$-ketamine in children. Anesthesiology, 2000;93(4):976-80.

8. Dahl, V, Raeder JC. Non-opioide postoperative analgesia. Acta Anaesthesiol Scand. 2004;44(10):1191-203.

9. Weinbroum AA. A single small dose of postoperative ketamine provides rapid and sustained improvement in morphine analgesia in the presence of morphine resistant pain. Anesth Analg. 2003;96(3):789-95.

10. Sveticic G, Eichenberger U, Curatolo M. Safety of mixture of morphine with ketamine for postoperative patient-controlled analgesia: an audit with 1026 patients. Acta Anaesthesiol Scand. 2005;49(6):870-5.

11. Laskowski K, Stirling A, McKay WP, Lim HJ. A systematic review of intravenous ketamine for postoperative analgesia. Can J Anesth. 2011;58(10):911-23.

12. Hardman JG, Limbird LE, Gilman AG. Goodman and Gilman's the Pharmacologyca Basis of Therapeutics. $10^{\text {th }}$ ed. New York: McGraw-Hill; 2001. 346-7p. 